\title{
URGENSI MODEL PEMBELAJARAN INTERAKTIF DALAM MENINGKATKAN PRESTASI DAN MOTIVASI BELAJAR SISWA DALAM MATA PELAJARAN PENDIDIKAN AGAMA ISLAM
}

\author{
FAUZI RAHMANUL HAKIM
}

\begin{abstract}
In learning Islamic Religious Education (PAI) students need a learning model that is appropriate and precise in its characteristics. Learning model is termed by interpreting a broader scope than the learning method or strategy. Therefore, the learning model can be interpreted as planning which is used as a reference or rule in the learning process carried out in the classroom and can be a determinant of learning equipment such as teaching materials, books, curriculum, and so on. So it can be said that the learning model is a directional framework from the educator for the teaching process. This research tries to present an overview of the learning problems of an interactive model in the practice of Islamic education. Islamic education is now faced with various kinds of challenges, demands and needs that have never existed before. So it is not enough with just one learning model, it takes innovation in the renewal of the learning model that is tailored to the system needs, curriculum, human resource competencies, infrastructure, and others. If not, then Islamic education in practice will be increasingly left behind because it becomes a problem of learning models that do not adapt to developments. This research uses a literature study approach, data collection through text studies, then the data obtained is analyzed using content analysis. This method intends to analyze the problems of interactive learning in Islamic education practices. So it becomes a solution if the urgency learning model is made into a good innovation from its weaknesses and strengths. Because the learning process of students will be considered more effective if students after learning can find out something that was not previously known. So, learning achievement will change for the better with a change in new behavior in the level of reason, knowledge, thinking or advancement of physical potential.
\end{abstract}

Keywords: Interactive learning, achievement, motivation, Islamic religious learning 


\section{Pendahuluan}

Pendidikan adalah usaha sadar dalam menempuh suatu berkemajuan, yang tadinya tidak bisa menjadi bisa, yang tadinya tidak baik menjadi baik, yang tadinya tidak disiplin menjadi disiplin. Dunia pendidikan memberikan solusi dari segala masalah, namun tentunya dalam pendidikan pun tidak luput dari yang namanya masalah, baik itu dalam perencanaan, proses pembelajaran, model pembelajaran, evaluasi bahkan masalah yang ada dari hasil pendidikan itu sendiri.

Dalam pendidikan secara sadar diusahakan oleh peserta didik dalam mengembangkan potensi yang dimilikinya supaya menjadi manusia yang memiliki keunggulan yang cakap dalam menghadapi bermacam problematika dan tantangan kehidupan. Pendidikan yang bertujuan memaksimalkan peserta didik agar dapat mengembangkan potensi yang sesuai dengan keinginan minat dan keberadaan bakatnya, tujuan pendidikan tersebut dapat berlangsung baik dengan pembelajaran secara aktif interaktif dan menyenangkan. Teknolologi dan informasi yang berkembang semakin canggih memberikan tantangan terhadap problematika baru di dunia pendidikan, sehingga membutuhkan usaha dan inovasi yang cepat, akurat sesuai perkembangan zaman, hal ini mendorong terjadinya proses perubahan dan perkembangan pendidikan nasional (Nita, 2018).

Sebagai proses penyempurnaan secara jasmani dan rohani yang ada dalam pendidikan, ini merupakan usaha dan ikhtiar sadar dalam peningkatan aspek akal peserta didik dalam meningkatkan potensi akal, potensi perasaan, dan potensi jiwa. Dilatihnya potensi fisik pada peserta didik adalah usaha untuk menjadikan kemampuan terampilnya yang menjadi keahlian peserta didik itu sendiri, bisa dikatakan keahlian profesional untuk modal hidup bermasyarakat. Maksimalnya kemapuan diri juga harus dimiliki oleh setiap peserta didik yang bisa memberikan kemanfaatan hidup di masyarakat umum, manfaat untuk pribadi, anggota keluarganya dan usaha dalam mencapai kebahagiaan hidup di dunia dan akhirat sebagai tujuan utamanya (Basri, 2009)

Pembelajaran yang efektif ditandai dengan berlangsungnya proses belajar mengajar yang mampu membelajarkan peserta didik dan mendapatkan prestasi belajar yang memuaskan. Proses belajar peserta didik akan dianggap lebih efektif apabila peserta didik setelah belajar bisa mengetahui sesuatu yang sebelumnya belum diketahui. Jadi, prestasi belajar akan berubah menjadi baik dengan adanya perubahan tingkah laku baru dalam tingkat akal pengetahuan, berpikir atau kemajuan potensi jasmaninya (Hamzah, 2007)

Demikian pula pembelajaran Pendidikan Agama Islam (PAI) membutuhkan model pembelajaran yang tepat dan sesuai dengan karakteristik peserta didik dalam belajar. Istilah model pembelajaran mempunyai arti yang sangat luas dari strategi, model, atau prosedur. Menurut 
Joyce model pembelajaran adalah suatu pola atau perencanaan yang dipakai sebagai petunjuk dalam mempersiapkan pembelajaran di kelas atau cara pembelajaran dan sebagai pilihan perangkat pembelajaran termasuk di dalamnya buku, film, komputer, kurikulm, dan lain sebaginya. Jadi model pembelajaran merupakan kerangka dan arah bagi pendidik untuk mengajar (Trianto, 2007)

Rendahnya prestasi belajar peserta didik pada mata pelajaran PAI dapat disebabkan beberapa faktor. Diantara faktor yang bisa menjadi penyebabnya antara lain: model pembelajaan yang kurang tepat, materi yang terlalu abstrak, cara mengajar pendidik yang kurang menarik, aktivitas peserta didik yang kurang optimal, tidak digunakannya media atau penggunaan media pembelajaran yang minim. Faktor peserta didik dan sarana pun sebetulnya dapat juga menjadi penyebabnya, namun penelitian ini yang akan memprioritaskan pada problematika model pembelajaran interaktif dalam praktik pendidikan Islam.

Berhasilnya proses pembelajaran Pendidikan Islam tidak akan terlepas dari kesiapan pendidik memodifikasi model pembelajaran yang mempunyai tujuan pada meningkatnya keterlibatan yang sering peserta didik secara baik dan efektif dalam proses belajar. Pengembangan model pembelajaran tepat pada dasarnya bertujuan untuk menciptakan kondisi pembelajaran yang memungkinkan peserta didik dalam belajar secara efektif dan interaktif juga menyenangkan sehingga peserta didik meraih prestasi belajar yang optimal (Aunurrahman, 2009)

Pendidikan Islam adalah usaha bimbingan kepada peserta didik supaya nantinya setelah usai dari pembelajaran dapat ngetahui dan memahami apa yang terpenting di dalam Islam secara menyeluruh, makna dan tujuan yang akan dihayati supaya pada akhirnya dapat mengamalkan serta menjadikan ajaran Islam yang telah dianutnya itu sebagai dasar hidup sehingga dapat menghadirkan keselamatan dunia dan akhirat (Daradjat, 2009).

Beberapa faktor yang bisa menjadi penyebab tidak maksimalnya prestasi peserta didik atau semangat dalam belajar antara lain: terlalu abstraknya materi bahan ajar, kurang menariknya penyampaian seorang pendidik, kurang aktifnya peserta didik, kurang optimalnya media yang digunakan sebagai bahan ajar, atau kurang tepatnya model pembelajaran. Sarana dan prasaranapun bisa menjadi penyebab dari hal tersebut, namun yang akan diperbaiki dalam penelitian ini fokusnya adalah kepada model pembelajaran (Aunurrahman, 2009).

Kemampuan peserta didik dalam mengembangkan model pembelajaran menjadi salah satu keberhasilannya proses pembelajaran dalam mata pelajaran pendidikan agama Islam yang fokus pada meningkatnya keaktifan peserta didik secara baik dalam proses belajarnya. Pada dasarnya model pembelajaran yang dikembangkan dengan baik bisa menjadikan tujuan dalam menciptakan suasana dan kondisi pembelajaran yang efektif, aktif serta 
membuat peserta didik ada dalam proses pembelajaran yang nyaman dan menyenangkan sehingga prestasi yang optimal dalam belajar dapat diraih.

Usaha mengoptimalkan prestasi belajar peserta didik adalah suatu citacita yang besar para pendidik disetiap sekolah. Pengembangan model pembelajaran sangat diinginkan untuk memudahkan peserta didik dalam memahami materi yang hasilnya dapat mengoptimalkan prestasi belajar peserta didik dalam pembelajaran pendidikan agama Islam.

Tidak ada satu model pembelajaran yang dapat diunggulkan, karena tiap-tiap model pembelajaran terasa baik apabila sesuai dengan meteri pelajaran tertentu. Mempelajari dan mengembangkan model pembelajaran bagi pendidik manjadi hal yang sangat pokok untuk diketahui. Dengan berkembangnya model-model pembelajaran, akan dirasakan oleh pendidik manfaat dan mudahnya pelaksanaan proses belajar di kelas, sehingga harapan tuntasnya belajar optimal akan mudah dicapai (Trianto, 2014).

Budaya sekolah dapat dibangun dengan pembiasaan yang bisa membentuk karakteristik tradisi sekolah, karena peradaban dibentuk dengan adanya pembiasaan. Kebiasaan bisa menjadikan kelakuan peserta didik baik aktif maupun pasif dalam prose pembelajarannya.

Nabi Muhammad sebagai contoh sentral panutan dan tauladan bagi umatnya, sebagaimana firman Allah SWT di dalam al-Qur'an (Abadi, 2001): "Sesungguhnya telah ada pada (diri) Rasulullah itu suri teladan yang baik bagimu (yaitu) bagi orang yang mengharap (rahmat) Allah dan (kedatangan) hari kiamat dan Dia banyak menyebut Allah". (Q.S. Al-Ahzab (33) ayat 21).

Substansi pembelajaran kuncinya adalah keteladanan, karena konkritnya tidak cukup diajarkan harus menjadi perilaku yang menjadi fungsi dari keteladanan.

Terdapat sejumlah model pembelajaran/belajar yang dapat dipergunakan oleh pendidik dalam kegiatan pembelajaran Pendidikan Agama Islam (PAI). Untuk dapat memilih model yang tepat dan sesuai, pendidik hendaknya memperhatikan prinsip-prinsip umum dan faktor-faktor yang mempengaruhinya penetapannya.

\section{Metode}

Kajian ini menggunakan metode survei pustaka, di mana penulis melakukan kajian terhadap sejumlah literatur yang relevan, yang berhubungan dengan model pembelajaran interaktif yang kemudian dihubungkan dengan upaya peningkatan motivasi pembelajaran mata pelajaran Pendidikan Agama Islam.

\section{Hasil Penelitian dan Pembahasan}

Model pembelajaran interaktif adalah suatu pendekatan belajar yang mengarah pada pandangan konstruktivisme. Model pembelajaran ini adalah salah satu alternatif pilihan model pembelajaran yang dapat menolong peserta 
didik untuk mampu mengungkapkan keingintahuannya dan ketidaktahuannya terhadap ilmu atau konsep yang sedang dipelajarinya (Widodo 2007). Sedangkan menurut Dasna pembelajaran interaktif mengarah pada interaksi antara pendidik dan peserta didik, penggajar dengan peserta didik, atau peserta didik dengan sumber belajar/media (Dasna 2015)

Menurut Faire \& Cosgrove dalam (Prayekti 2004) model pembelajaran interaktif terkenal dengan nama pendekatan pertanyaan peserta didik. Model ini dibuat supaya peserta didik mengeluarkan pertanyaan serta menemukan jawaban pertanyaan dari peserta didik itu sendiri. Adanya pendapat yang telah diketahui, bahwa model pembelajaran interaktif akan dapat dipahami oleh peserta didik sebagai pembelajaran yang menitik beratkan pada komunikasi antar peserta didik maupun guru dengan peserta didik melalui interaksi langsung dengan sumber belajarnya. Komunikasi dapat terjalin dari pemberian stimulus-stimulus untuk menggali pertanyaan-pertanyaan siswa sebagai ungkapan rasa ingin tahu seswa terhadap pengetahuan yang akan dipelajari (Ali 2009).

Pertanyaan peserta didik merupakan ciri khasnya dalam model pembelajaran interaktif. Pada model pembelajaran interaktif yang akan sering ditekankan muncul adalah pertanyaan-pertanyaan, dan pertanyaan dimungkinkan bermacam-macam. Menurut Louisel \& Descamps dalam (Majid 2014) pertanyaan dalam proses pembelajaran interaktif memiliki tiga tujuan inti, yakni bisa meningkatkan tingkat berpikir peserta, mengetahui sejauh mana pemahaman siswa, dan bisa meningkatnya keaktifan belajar peserta didik.

Menjelaskan Suparman dalam (Majid 2014) bahwa "model pembelajaran interaktif mempunyai tujuh ciri, (1) adanya variasi dalam kegiatan klasikal, individu, dan kelompok, (2) adanya aspek mental (potensi akal dan emosi) peserta didik yang tinggi, (3) pendidik mempunyai peran menjadi narasumber, fasilitator, dan pemimpin atau manajer kelas yang demokratis, (4) menjadikan pola komunikasi disegala arah, dan (5) mempunyai suasana kelas yang baiakm fleksibel, demokratis, menantang, dan tetap terarah pada tujuan, (6) semua potensi akan menghasilkan dampak peserta didik lebih efektif, (7) dapat digunakan indoor maupun outdor."

Suatu model pembelajaran dapat berhasil diterapkan dengan baik apabila dilaksanakan sesuai dengan langkah-langkah model tersebut. Menurut Emma Holmes dalam (Irsyadi 2011) model pembelajaran interaktif dilakukan pada lima langkah yaitu, (1) dimulai dengan adanya pengantar (introduction), (2) hadirnya aktivitas/pemecahan masalah (activity/problem solving), (3) ada tahapan saling membagi serta diskusi (sharing and discussing), (4) tahapan meringkas (summaring), (5) adanya penilaian terhadap unit belajar materi (assessment of learning of unit material).

Sedangkan menurut Faire \& Cosgrove dalam (Widodo 2007), ada tujuh tahapan dalam model pembelajaran interaktif, yaitu: "pertama adalah adanya 
tahap persiapan, dalam tahap ini pendidik dan peserta didik mencari dan memilih informasi tentang topik apa yang melatar belakangi pembelajaran, lalu mengumpulkan sumber yang ada kaitannya dengan materi pembahasan yang akan dipelajari. Kedua adalah adanya tahap pengetahuan awal, dalam tahap ini pendidik berusaha mengemukakan pengetahuan awal tentang topik pembelajaran yang akan dipelajari. Ketiga adalah adanya tahap kegiatan eksplorasi, pendidik memberikan penjelasan terkait topik pembelajaran yang ingin di kembangkan. Dalam kegiatan eksplorasi atau mengembangkan peserta didik dilibatkan lebih aktif terkait topik pembelajaran yang dipelajari. Dengan demikian peserta didik diberi stimulus untuk mengusulkan pertanyaan. Keempat adalah adanya tahap pertanyaan peserta didik, pada tahap ini seluruh peserta didik diajak untuk memberikan pertanyaan mengenai topik pembelajaran yang dipelajari. Kelima adalah adanya tahap penyelidikan, pada tahap ini pendidik dan peserta didik memilih pertanyaanpertanyaan yang akan dicari jawabannya melalui penyelidikan. Keenam adalah adanya tahap pengetahuan akhir, pada tahap ini pengetahuan masingmasing peserta didik bisa dikelompokan atau dikumpulkan dan dibandingkan dengan jawaban yang awal. Ketujuh adalah adanya tahap refleksi, pada tahap ini akumulasi apa yang telah diuji atau bisa dibuktikan dan apa yang masih perlu dimantapkan sebelumnya. Jika masih ada pertanyaan yang menyusul pada penerapan model pembelajaran interaktif sebagai usaha untuk meningkatkan aktivitas pembelajaran dan hasil belajar.

Perlu diketahui pada tahap refleksi ini kalaulah konsepnya belum terlalu dikuasai dengan baik, maka perlu diulang ke tahap penyelidikan. Merupakan pendapat para ahli, penelitian ini mengarah pada dasar langkahlangkah model pembelajaran interaktif menurut Holmes yaitu: (Suharso 2012)

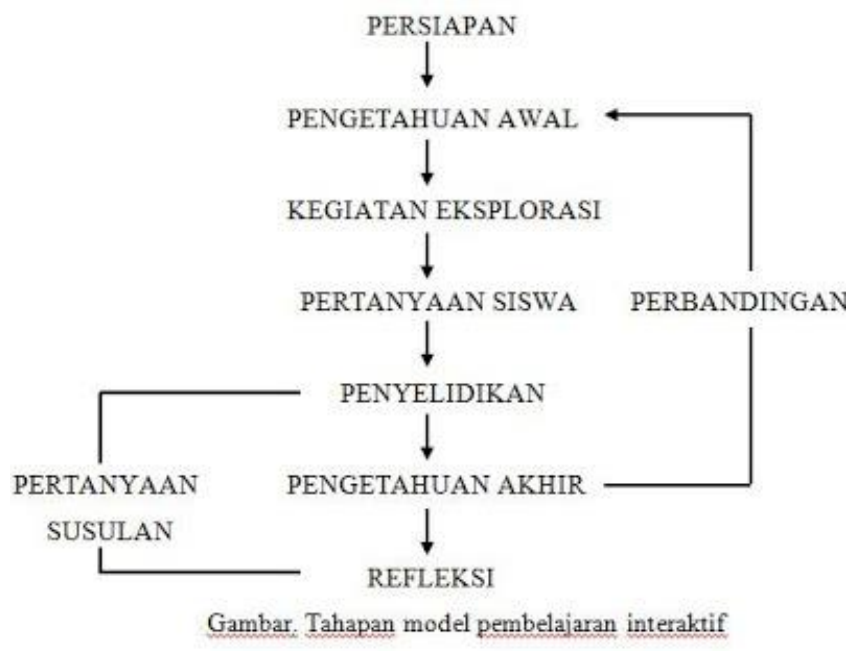


Table. Langkah-langkah Model Pembelajaran Interaktif (Widiantono 2017)

\begin{tabular}{|c|c|c|}
\hline No & Tahapan & Aktivitas \\
\hline 1 & Tahap pengantar & $\begin{array}{l}\text { Pada tahap pengorganisasian kelas untuk adanya } \\
\text { pembelajaran (kerja individual/kerja kelompok). } \\
\text { Sebagai pengetahuan awal peserta didik harus } \\
\text { menyelidiki dengan pertanyaan yang diajukan } \\
\text { dalam permasalahan yang sudah ditentukan. Setelah } \\
\text { itu peserta didik harus menemukan dan } \\
\text { menyampaikan penelitian yang ditemukan oleh } \\
\text { peserta didik, contohnya adanya menyelesaian } \\
\text { problem/masalah oleh peserta didik, peserta didik } \\
\text { melakukan aktivitas (adanya penyelidikan, } \\
\text { percobaan pada tugas, memberikan pengamatan } \\
\text { penelitian, atau melakukan Tanya jawab juga } \\
\text { diskusi), kemudian melanjutkan/mempelajari topik, } \\
\text { serta peserta didik mengerjakan tugas (proyek). }\end{array}$ \\
\hline 2 & $\begin{array}{l}\text { Tahap aktivitas } \\
\text { penyelesaian } \\
\text { masalah }\end{array}$ & $\begin{array}{l}\text { Pada model interaktif aktivitas penyelesaian } \\
\text { masalah adalah tahap inti, dikarenakan tahap ini } \\
\text { melibatkan peserta didik untuk mengolah pikir dan } \\
\text { memplanigkan apa yang harus dicari dari materi } \\
\text { pembelajaran, dan pembagian proyek (kelompok). } \\
\text { Pendidik harus mengamati, membimbing peserta } \\
\text { didik, dan memberikan komentar terhadap tugas } \\
\text { proyek peserta didik. Pada tahap ini akan terlihat } \\
\text { menonjol bagaimana situasi interaktif antar peserta } \\
\text { didik, antar peserta didik dalam kelompok, maupun } \\
\text { antar peserta didik dengan guru. }\end{array}$ \\
\hline 3 & $\begin{array}{lr}\text { Tahap } & \text { saling } \\
\text { berbagi } & \text { dan } \\
\text { diskusi } & \end{array}$ & $\begin{array}{l}\text { Pada tahap ini peserta didik harus mampu } \\
\text { melaporkan hasil tugas/proyek penyelidikannya } \\
\text { atau penyelesaian problem/masalah dari } \\
\text { pertanyaan peserta didik sendiri (individu) atau } \\
\text { kelompok, kesimpulan akan ditemukan pada } \\
\text { pelaporan ketika peserta didik melakukan } \\
\text { presentasi atau Tanya jawab/diskusi saling } \\
\text { mengemukakan pendapat. Sementara pendidik } \\
\text { harus bisa mengatur, memimpin perjalanan diskusi, } \\
\text { mengawasi proses presentasi, dan memberikan } \\
\text { komentar pada kegiatan diskusi atau presentasi } \\
\text { dengan mengemukakan pertanyaan apa, bagaimana, } \\
\text { dan mengapa. Dengan melalui pertanyaan itu akan } \\
\text { dimungkinkan peserta didik terlatih untuk berpikir } \\
\text { lebih tinggi dalam menghubungkan fakta-fakta yang }\end{array}$ \\
\hline
\end{tabular}




\begin{tabular}{|l|l|l|}
\hline & & $\begin{array}{l}\text { mereka temukan dari pengalaman dengan } \\
\text { pengetahuan awal mereka, menjadi konsep atau } \\
\text { ilmu pengetahuan baru yang dipahami peserta didik. }\end{array}$ \\
\hline 4 & Tahap meringkas & $\begin{array}{l}\text { Pada tahap ini peserta didik memeriksa kembali apa } \\
\text { yang telah dilakukan atau dipejari peserta didik. } \\
\text { Kemudian membuat laporan hasil tugas/kegiatan } \\
\text { peserta didik berdasarkan pengalaman peserta didik } \\
\text { itu sendiri dan apa yang telah peserta didik pelajari } \\
\text { secara ilmiah dengan bimbingan pendidik. }\end{array}$ \\
\hline 5 & $\begin{array}{l}\text { Tahap menilai } \\
\text { belajar }\end{array}$ & $\begin{array}{l}\text { Dalam tahap ini dilakukan penilaian pembelajaran, } \\
\text { peserta didik dan pendidik bersama-sama menilai } \\
\text { kegiatan pembelajaran dari awal sampai akhir } \\
\text { proses pembelajaran. Sehingga peserta didik } \\
\text { diharapkan dapat menguasai meteri dengan baik. }\end{array}$ \\
\hline
\end{tabular}

Menurut Renny dalam (Majid 2014) model pembelajaran interaktif mempunyai enam kelebihan yaitu, (1) peserta didik diberikan lebih kesempatan untuk melibatkan pengalaman keingin tahuannya kepada objek yang akan dipelajarinya. (2) peserta didik dilatih mengungkapkan pengetahuannya melalui pertanyaan-pertanyaan yang dikemukakan kepada pendidik. (3) model interaktif ini memberikan sarana bermain bagi peserta didik melalui kegiatan pengembangan/eksplorasi dan penelitian/investigasi. (4) pendidik menjadi fasilitator, motivator pengetahuan, dan perancang tugas aktivitas belajar peserta didik. (5) menempatkan peserta didik sebagai subjek pembelajaran yang aktif. (6) hasil belajar akan lebih dirasakan bermakna.

Sementara kekurangan dari model pembelajaran interaktif yaitu keberhasilan pembelajaran bergantung pada kemampuan dan kecakapan pendidik sebagai narahubung atau fasilitator dan manajer kelas dalam berkomunikasi dari berbagai arah untuk mengembangkan proses dinamika kelompok (Nurdyansyah and Fahyuni 2016).

Kekurangan tersebut dapat diatasi atau diminimalisir dengan memberikan pengertian kepada peserta didik tentang dinamika kelompok. Dinamika kelompok menurut (Santosa 2004) merupakan suatu kelompok yang teratur dari dua peserta didik atau lebih yang mempunyai hubungan psikologis secara jelas antara peserta didik yang satu dengan yang lain, antar peserta didik pada kelompok mempunyai hubungan psikologis yang berlangsung dalam situasi yang dialami secara bersama-sama.

\section{Karakteristik Model Pembelajaran Interaktif}

Model pembelajaran interaktif adalah suatu pendekatan belajar yang mengarah pada pandangan konstruktivisme. Model pembelajaran ini adalah salah satu alternatif pilihan model pembelajaran yang dapat menolong peserta didik untuk mampu mengungkapkan keingintahuannya dan ketidaktahuannya 
terhadap ilmu atau konsep yang sedang dipelajarinya (Widodo, 2007). Sedangkan menurut Dasna pembelajaran interaktif mengarah pada interaksi antara pendidik dan peserta didik, penggajar dengan peserta didik, atau peserta didik dengan sumber belajar/media (Dasna, 2015)

Menurut Faire \& Cosgrove model pembelajaran interaktif terkenal dengan nama pendekatan pertanyaan peserta didik. Model ini dibuat supaya peserta didik mengeluarkan pertanyaan serta menemukan jawaban pertanyaan dari peserta didik itu sendiri (Prayekti, 2004). Adanya pendapat yang telah diketahui, bahwa model pembelajaran interaktif akan dapat dipahami oleh peserta didik sebagai pembelajaran yang menitik beratkan pada komunikasi antar peserta didik maupun guru dengan peserta didik melalui interaksi langsung dengan sumber belajarnya. Komunikasi dapat terjalin dari pemberian stimulus-stimulus untuk menggali pertanyaanpertanyaan siswa sebagai ungkapan rasa ingin tahu seswa terhadap pengetahuan yang akan dipelajari (Ali, 2009).

Pertanyaan peserta didik merupakan ciri khasnya dalam model pembelajaran interaktif. Pada model pembelajaran interaktif yang akan sering ditekankan muncul adalah pertanyaan-pertanyaan, dan pertanyaan dimungkinkan bermacam-macam. Menurut Louisel \& Descamps pertanyaan dalam proses pembelajaran interaktif memiliki tiga tujuan inti, yakni bisa meningkatkan tingkat berpikir peserta, mengetahui sejauh mana pemahaman siswa, dan bisa meningkatnya keaktifan belajar peserta didik (Majid, 2014).

Suparman menjelaskan diantaranya adalah bahwa "model pembelajaran interaktif mempunyai tujuh ciri, (1) adanya variasi dalam kegiatan klasikal, individu, dan kelompok, (2) adanya aspek mental (potensi akal dan emosi) peserta didik yang tinggi, (3) pendidik mempunyai peran menjadi narasumber, fasilitator, dan pemimpin atau manajer kelas yang demokratis, (4) menjadikan pola komunikasi disegala arah, dan (5) mempunyai suasana kelas yang baiakm fleksibel, demokratis, menantang, dan tetap terarah pada tujuan, (6) semua potensi akan menghasilkan dampak peserta didik lebih efektif, (7) dapat digunakan indoor maupun outdor" (Majid, 2014).

Suatu model pembelajaran dapat berhasil diterapkan dengan baik apabila dilaksanakan sesuai dengan langkah-langkah model tersebut. Menurut Emma Holmes model pembelajaran interaktif dilakukan pada lima langkah yaitu, (1) dimulai dengan adanya pengantar (introduction), (2) hadirnya aktivitas/pemecahan masalah (activity/problem solving), (3) ada tahapan saling membagi serta diskusi (sharing and discussing), (4) tahapan meringkas (summaring), (5) adanya penilaian terhadap unit belajar materi (assessment of learning of unit material) (Irsyadi, 2011).

Sedangkan menurut Faire \& Cosgrove, ada tujuh tahapan dalam model pembelajaran interaktif, yaitu: "pertama adalah adanya tahap persiapan, dalam tahap ini pendidik dan peserta didik mencari dan memilih informasi 
tentang topik apa yang melatar belakangi pembelajaran, lalu mengumpulkan sumber yang ada kaitannya dengan materi pembahasan yang akan dipelajari. Kedua adalah adanya tahap pengetahuan awal, dalam tahap ini pendidik berusaha mengemukakan pengetahuan awal tentang topik pembelajaran yang akan dipelajari. Ketiga adalah adanya tahap kegiatan eksplorasi, pendidik memberikan penjelasan terkait topik pembelajaran yang ingin di kembangkan. Dalam kegiatan eksplorasi atau mengembangkan peserta didik dilibatkan lebih aktif terkait topik pembelajaran yang dipelajari. Dengan demikian peserta didik diberi stimulus untuk mengusulkan pertanyaan. Keempat adalah adanya tahap pertanyaan peserta didik, pada tahap ini seluruh peserta didik diajak untuk memberikan pertanyaan mengenai topik pembelajaran yang dipelajari. Kelima adalah adanya tahap penyelidikan, pada tahap ini pendidik dan peserta didik memilih pertanyaan-pertanyaan yang akan dicari jawabannya melalui penyelidikan. Keenam adalah adanya tahap pengetahuan akhir, pada tahap ini pengetahuan masing-masing peserta didik bisa dikelompokan atau dikumpulkan dan dibandingkan dengan jawaban yang awal. Ketujuh adalah adanya tahap refleksi, pada tahap ini akumulasi apa yang telah diuji atau bisa dibuktikan dan apa yang masih perlu dimantapkan sebelumnya. Jika masih ada pertanyaan yang menyusul pada penerapan model pembelajaran interaktif sebagai usaha untuk meningkatkan aktivitas pembelajaran dan hasil belajar (Widodo, 2007).

Perlu diketahui pada tahap refleksi ini kalaulah konsepnya belum terlalu dikuasai dengan baik, maka perlu diulang ke tahap penyelidikan, kemampuan peserta didik akan diketahui oleh pendidik yang memanfaatkan munculnya pertanyaan-pertanyaan yang muncul. Louisel dan Descamps, berpendapat bahwa ada tiga tujuan pertanyaan inti dalam proses pembelajaran, yaitu: 1) Meningkatkan tingkat berpikir peserta didik, 2) Mengecek pemahaman peserta didik, 3) Meningkatkan partisipasi belajar peserta didik (Majid, 2013).

Karakteristik yang dimiliki dalam pembelajaran interaktif ini adalah: a) Adanya kegiatan klasikal yang bervariasi, individu, dan kelompok, b) memiliki mental yang baik, c) peran fasilitator, narasumber, dan manajer kelas demokratis yang dimiliki oleh pendidik, d) komunikasi polanya tidak satu arah, e) Terkendalinya suasana kelas dan tetap sesuai dengan tujuan, f) Potensi berdampak lebih efektif, g) Dapat digunakan indor maupun outdor (Majid, 2014).

Ada syarat-syarat yang harus diketahui oleh pendidik dalam pengembangan pembelajaran interaktif yaitu model pembelajaran: 1) harus dapat membangkitkan motivasi, minat atau gairah belajar peserta didik, 2) dapat merangsang keinginan peserta didik untuk belajar lebih lanjut, seperti melakukan interaksi dengan pendidik dan peserta didik lainnya, 3) mampu memberikan kesempatan bagi peserta didik untuk memberikan tanggapannya terhadap materi yang disampaikan, 4) menjamin perkembangan kegiatan 
kepribadian peserta didik, 5) dapat mendidik peserta didik dalam teknik belajar sendiri dan cara memperoleh pengetahuan melalui usaha pribadi, 6) dapat menanamkan dan mengembangkan nilai-nilai dan sikap peserta didik dalam kehidupan sehari-hari (Majid, 2014).

Pendidik mempunyai peran dengan peserta didik dalam belajar, terutama dalam hal pengembangan keterampilan, ada tiga keterampilan yang harus diketahui. Ketiga keterampilan tersebut dapat dikembangkan dalam situasi belajar mengajar yang interaktif antara pendidik dengan peserta didik, dan peserta didik dengan peserta didik. Antara lain keterampilan praktis, keterampilan berpikir dan keterampilan sosial (Andayani, 2005).

Model interaktif kegiatannya diprioritaskan kepada proses belajar, bukan pada hasil. Jadi yang paling ditekankan itu adalah menyusun dan mengembangkan strategi bagaimana peserta didik mendapatkan ilmu pengehatuan dengan cara mengalami, bukan menghafal

\section{Faktor-faktor yang Berpengaruh terhadap Prestasi Belajar}

Ada beberapa faktor yang dapat mempengaruhi prestasi belajar, di antaranya faktor guru, faktor siswa, sarana, alat dan media yang tersedia, serta faktor lingkungan (Sanjaya, 2007).

Faktor Guru

Guru adalah komponen yang sangat menentukan dalam pelaksanaan suatu strategi pembelajaran. Tanpa guru, bagaimanapun bagus dan idealknya suatu strategi, maka strategi itu tidak mungkin dapat dilaksanakan. Layaknya seorang prajurit di medan pertempuran. Keberhasilan penerapan strategi berperang untuk menghancurkan musuh akan sangat bergantung pada kualitas prajurit itu sendiri. Demikian juga dengan guru, keberhasilan pelaksanaan suatu strategi pembelajaran akan tergantung pada kepiawaian guru dalam menggunakan metode, teknik dan taktik pembelajaran. Diyakini setiap guru akan memiliki pengalaman, pengetahuan, kemampuan, gaya dan bahkan pandangan yang berbeda dalam mengajar. Guru yang menganggap mengajar hanya sebatas menyampaikan mengajar adalah suatu proses pemberian bantuan kepada peserta didik. Masing-masing perbedaan tersebut dapat mempengaruhi baik dalam penyusunan strategi atau pelaksanaan pembelajaran.

Faktor Siswa

Siswa adalah organisme yang unik yang berkembang sesuai dengan tahap perkembangannya. Perkembangan anak adalah perkembangan seluruh aspek kepribadiannya, akan tetapi tempo dan irama perkembangan masingmasing anak pada setiap aspek tidak selalu sama. Kegiatan pembelajaran bisa dipengaruhi dengan perkembangan peserta didik yang tidak sama, baik dari karakteristik yang melekat pada diri peserta didik.

Aspek latar belakang meliputi jenis kelamin siswa, tempat kelahiran, tempat tinggal siswa, tingkat sosial ekonomi siswa, dari keluarga yang 
bagaimana siswa berasal, dan lain-lain. Sedangkan dilihat dari sifat yang dimiliki siswa meliputi kemampuan dasar, pengetahuan dan sikap. Tidak dapat disangkal bahwa setiap siswa memiliki kemampuan yang berbeda yang dapat dikelompokkan pada siswa berkemampuan tinggi, sedang, dan rendah. Siswa yang termasuk berkemampuan tinggi biasanya ditunjukkan oleh motivasi yang tinggi dalam belajar, perhatian dan keseriusan dalam mengikuti pelajaran dan lain-lain. Sebaliknya siswa yang tergolong pada kemampuan rendah ditandai dengan kurangnya motivasi belajar, tidak ada keseriusan dalam mengikuti pelajaran, termasuk menyelesaikan tugas, dan lain sebagainya. Perbedaan-perbedaan semacam itu menuntut perlakuan yang berbeda pula baik dalam penempatan atau pengelompokkan siswa maupun dalam perlakuan guru dalam menyesuaikan gaya belajar. Demikian juga halnya dengan tingkat pengetahuan siswa. Siswa yang memiliki pengetahuan yang memadai tentang penggunaan bahasa standar, misalnya akan mempengaruhi proses pembelajaran mereka dibandingkan dengan siswa yang tidak memiliki tentang hal itu.

\section{Faktor Sarana dan Prasarana}

Sarana yaitu segala aspek yang mendukung baik secara langsung maupun tidak langsung terhadap kelancaran kegiatan atau proses pembelajaran, contohnya media pembelajaran, perlengkapan sekolah, alat-alat pelajaran dan yang lainnya. Sedangkan prasarana adalah segala sesuatu yang secara tidak langsung dapat mendukung keberhasilan proses dan hasil pembelajaran, misalnya jalan menuju sekolah, penerangan sekolah, kamar kecil, dan lain sebagainya. Kelengkapan sarana dan prasarana akan membantu guru dalam menyelenggarakan proses pembelajaran. Dengan demikian, sarana dan prasarana merupakan komponen penting yang dapat mempengaruhi proses pembelajaran.

\section{Faktor Lingkungan}

Dilihat dari dimensi lingkungan ada dua faktor yang dapat mempengaruhi proses dan hasil pembelajaran yaitu faktor organisasi kelas dan faktor iklim sosial-psikologis.

Faktor organisasi kelas yang di dalamnya meliputi jumlah siswa dalam satu kelas merupakan aspek penting yang dapat mempengaruhi proses dan hasil pembelajaran. Organisasi di kelas yang terlalu banyak akan menjadi kurang efektif untuk mencapai suatu tujuan pembelajaran. Kelompok belajar yang besar dalam satu kelas memiliki kecenderungan sebagai berikut: Sumber daya kelompok akan bertambah luas sesuai dengan jumlah siswa, sehingga waktu yang tersedia akan semakin sempit, kelompok belajar akan kurang mampu memanfaatkan dan menggunakan semua sumber daya yang ada. Misalnya dalam penggunaan waktu diskusi. Jumlah siswa yang terlalu banyak akan memakan waktu yang banyak pula, sehigga sumbangan pikiran akan sulit didapatkan dari setiap siswa, kepuasan belajar setiap siswa akan cenderung menurun. Hal ini disebabkan kelompok belajar yang terlalu banyak 
akan mendapatkan pelayanan yang terbatas dari setiap guru, dengan kata lain perhatian guru akan semakin terpecah, perbedaan individu antara anggota akan semakin tampak, sehingga akan semakin sukar mencapai kesepakatan. Kelompok yang terlalu besar cenderung akan terpecah ke dalam sub-sub kelompok yang bertentangan, anggota kelompok yang terlalu banyak akan cenderungan semakin banyaknya siswa yang enggan berpartisipasi aktif dalam setiap kegiatan kelompok (Sanjaya, 2007).

Memperhatikan beberapa kecenderungan tersebut, maka jumlah anggota kelompok besar akan menguntungkan dalam menciptakan iklim belajar mengajar yang baik. Faktor lain dari dimensi lingkungan yang dapat mempengaruhi proses pembelajaran adalah faktor iklim sosial-psikologis, yang dimaksud adalah adanya keharmonisan antara individu yang terlibat dalam proses pembelajaran. Iklim sosial ini dapat terjadi secara internal atau eksternal.

Iklim sosial-psikologis secara internal adalah hubungan antara orang yang terlibat dalam lingkungan sekolah, misalnya iklim sosial antara siswa dengan siswa, antara siswa dengan guru, antara guru dengan guru, bahkan antara guru dengan pimpinan sekolah. Iklim sosial-psikologis eksternal adalah keharmonisan hubungan antara pihak sekolah dengan dunia luar, misalnya hubungan sekolah dengan orangtua siswa, hubungan sekolah dengan lembaga-lembaga masyarakat, dan lain sebagainya.

Faktor Kurikulum

Kurikulum adalah suatu rancangan yang berisikan pengaturan tentang tujuan, isi, bahan pelajaran dan cara yang digunakan dalam penyelenggaraan kegiatan belajar mengajar untuk mencapai tujuan pendidikan sesuai yang diharapkan.

Perkembangan kurikulum sebagai satu proses merupakan putaran asas yang mengandung : menganalisis, membentuk, melaksanakan dan menilai. Proses perkembangan kurikulum ini dapat dipakai di semua hasil atau peringkat dalam pembentukan konsep dan memadukan semua usaha dalam meningkatkan kualitas program sekolah. Kurikulum yaitu semua pengalaman proses pembelajaran yang sengaja dirancang direncanakan dan diarahkan oleh suatu sekolah dalam mencapai tujuan pendidikan. Di dalam kurikulum akademik, terdapat berbagai macam juga jenis kurikulum, seperti adanya kurikulum integrasi, aktivitas atau pengalaman yang bisa digabungkan untuk menjadikan kurikulum formal. Pembentukkan dan perubahan dalam kurikulum dipengaruhi oleh polisi-polisi kerajaan, matlamat dan keutamaan program, keperluan negara dan masyarakat, keperluan individu serta keperluan menyeluruh. 


\section{Konsep Motivasi Belajar}

Ada beberapa pendapat di antara para ahli dalam pengertian motivasi ahli yang satu mempunyai batasan lain, bila dibanding dengan batasan ahli lainnya. Untuk memberi gambaran mengenai pengertian motivasi penulis memandang perlu mengkaji berbagai pendapat para ahli, antara lain dikemukakan oleh Sardiman "motivasi adalah perubahan energi dalam diri seseorang yang ditandai dengan adanya feeling serta didahului dengan adanya tanggapan terhadap suatu adanya tujuan" (Sardiman, 2012). Menurut Purwanto bahwa "motivasi atau dorongan adalah satu pernyataan yang kompleks di dalam suatu organisme yang mengarahkan tingkah laku terhadap suatu tujuan (pola) atau perangsang" (Purwanto, 2004). Adapun pengertian motivasi menurut Syah Muhibbin "Motivasi adalah suatu proses untuk menggiatkan dorongan menjadi perbuatan atau tingkah laku, yang mengatur tingkah laku atau perbuatan untuk memuaskan kebutuhan atau mencapai tujuan" (Muhibbin, 2000).

Motivasi merupakan pendorong bagi perbuatan seseorang berkenaan dengan tindakan atau perilakunya. Dalam konteks kehidupan sehari-hari kita sering menggunakan kata motif sebagai bentuk kata dasar motivasi. Motif merupakan keadaan dalam pribadi orang yang mendorong individu untuk melakukan aktivitas-aktivitas tertentu guna mencapai tujuan. Sedangkan motivasi adalah pendorong atau suatu usaha yang didasari untuk mempengaruhi tingkah laku seseorang agar melakukan suatu perbuatan sehingga mencapai tujuan yang diharapkannya (Suryabrata, 1994).

Sejalan dengan hal itu, Effendi dan Praja menyatakan bahwa "Motivasi adalah suatu kondisi/kekuatan/dorongan yang menggerakkan organisme (individu) untuk mencapai tujuan pada tingkat tertentu". Dengan kata lain, motif itu yang menyebabkan timbulnya semacam kekuatan agar individu itu berbuat dan bertingkah laku. Pergertian lain tentang motif dikemukakan Maslow bahwa "motif bukanlah yang dapat diambil, tetapi merupakan hal yang dapat disimpulkan oleh adanya sesuatu yang dapat disaksikan" (Praja, 1999).

Sejalan dengan pendapat tersebut, motivasi belajar peserta didik dipengaruhi oleh dua faktor yaitu faktor internal (dari dalam diri individu) dan faktor eksternal (dari luar diri individu). Demikian pula menurut Purwanto mengemukakan bahwa "motivasi belajar dapat dibedakan menjadi dua yaitu (1) motif intrinsik dan (2) motif ekstrinsik". Motif intrinsik adalah motivasi yang mendorong peserta didik untuk bertindak yang di dalamnya terkandung nilai-nilai bagi seorang individu (Purwanto, 2004). Sedangkan motivasi ekstrinsik motif yang muncul dari luar diri individu untuk belajar. Motivasi belajar peserta didik tersebut ditandai (memiliki indikator) yang meliputi : "(1) sebagai hasil dari kebutuhan belajar peserta didik, (2) terarah kepada suatu tujuan pembelajaran, (3) menopang perilaku belajar peserta didik" (Surya, 2004). 
Dari beberapa pengertian di atas dapat disimpulkan bahwa motivasi merupakan dorongan-dorongan secara sadar yang mendasari seseorang untuk melakukan aktivitas-aktivitas tertentu untuk mencapai tujuannya. Dengan kata lain, kekuatan yang mendorong seseorang untuk melakukan suatu yang pada dasarnya dirangsang oleh adanya berbagai macam kebutuhan atau keinginan yang hendaknya dicapai.

Motivasi bisa disebut serangkaian usaha dalam menyediakan situasi dan kondisi tertentu sehingga individu mau dan ingin melakukan sesuatu, apabila individu tersebut tidak senang maka akan hilanglah rasa tidak sukanya tersebut. Motivasi akan muncul dengan rangsangan dari luar walaupun itu tumbuh dalam diri seseorang.

Dari kegiatan belajar maka motivasi dapat dikatakan sebagai keseluruhan daya pengurai sebagai keseluruhan daya penggerak dalam diri peserta didik yang dapat menimbulkan kegiatan belajar, yang menjamin dari kegiatan belajar untuk berlangsung terus dan memberikan arah pada kegiatan belajar, sehingga tujuan dikehendaki oleh subjek belajar akan dapat tercapai.

Selanjutnya dalam hubungan dengan proses belajar mengajar, yang terpenting adalah bagaimana menciptakan kondisi atau suatu proses yang mengarahkan peserta didik untuk melakukan aktivitas belajar. Bagaimana guru melakukan usaha-usaha untuk dapat menumbuhkan memberikan motivasi agar peserta didiknya melakukan aktivitas dengan baik. Sardiman (Sardiman 2012) mengemukakan bahwa "Memberikan motivasi kepada seorang peserta didik berarti menggerakkan peserta didik untuk melakukan sesuatu atau ingin melakukan sesuatu".

Dari uraian tersebut di atas, maka dapat disimpulkan bahwa motivasi belajar adalah keseluruhan daya penggerak di dalam diri peserta didik yang menimbulkan kegiatan belajar, yang dapat menjamin kelangsungan dari proses belajar sehingga tujuan individu yang diinginkan oleh individu pembelajar itu dapat tercapai. Dikatakan keseluruhan karena pada umumnya ada beberap motif yang bersama-sama menggerakan untuk belajar. Motivasi belajar adalah yang merupakan faktor psikis yang bersifat non-intelektual (Sardiman, 2012).

Ciri-ciri motivasi belajar yang ada pada diri setiap orang diantaranya tekun menghadapi tugas (dapat bekerja terus menerus dalam waktu lama, tidak pernah berhenti sebelum selesai), ulet menghadapi kesulitan (tidak lekas putus asa) memerlukan dorongan dari luar untuk berprestasi sebaik mungkin (tidak cepat) puas dengan prestasi yang telah dicapainya), menunjukan minat terhadap macam-macam masalah untuk orang dewasa (misalnya masalah pembangunan agama, politik, ekonomi, keadilan, pemberantasan korupsi, penentangan terhadap setiap tindak kriminal amoral dan sebagainya), lebih senang bekerja sendiri, cepat bosan pada tugas-tugas rutin (hal-hal yang bersifat mekanis, berulang-ulang begitu saja, sehingga 
kurang kreatif), dapat mempertahankan pendapatnya (kalau sudah yakin akan sesuatu), dan senang mencari dan memecahkan soal-soal (Sardiman, 2012).

Demikian ciri-ciri motivasi belajar, apabila seseorang memiliki ciri-ciri tersebut di atas, berarti telah memiliki motivasi belajar yang kuat. Dalam kegiatan (proses) belajar mengajar akan berhasil baik, kalau peserta didik tekun mengerjakan tugas, ulet dalam memecahkan berbagai masalah dan hambatan secara madiri. Hal-hal ini harus dipahami benar oleh guru, agar dalam berinteraksi dapat memberikan motivasi yang tepat dan optimal

\section{Kesimpulan}

Pembelajaran interaktif adalah salah satu model penunjang belajar dalam proses pendidikan, sebagai usaha pendidik dalam melaksanakan perencanaan, proses, evaluasi dan hasil dari pembelajaran. Upaya ini dilakukan untuk mempercepat kelambanan dalam belajar peserta didik dalam melaksanakan kegiatan belajarnya. Model interaktif kegiatannya diprioritaskan pada proses belajar, bukan pada hasil. Jadi yang paling ditekankan adalah mengembangkan strategi bagaimana peserta didik mendapatkan ilmu pengetahuan dengan mengalami suatu pengalaman, bukan menghafal. Tahapan dari pembelajaran interaktif adalah tahapan persiapan, pengetahuan awal, kegiatan eksplorasi, pertanyaan siswa, penyelidikan, pengetahuan akhir, dan refleksi.

Dalam pembelajaran pendidikan Islam peserta didik membutuhkan model pembelajaran yang sesuai dan tepat dalam karakteristiknya. Model pembelajaran diistilahkan dengan memaknai luas cakupannya dari pada metode atau strategi pembelajaran. Maka dari itu untuk pendidikan Islam dibutuhkan model pembelajaran yang tepat, diantaranya menggunakan model pembelajaran interaktif, walaupun belum sepenuhnya keberhasilan belajar menggunakan satu model pembelajaran saja.

Adanya problem pembelajaran interaktif dalam praktik pendidikan Islam, diantaranya problem peserta didik, problem pendidik, dan problem kurikulum. Peserta didik yang belum sepenuhnya siap dalam model pembelajaran diterapkan, belum siapnya mental peserta didik dalam mengajukan pertanyaan, melakukan penyelidikan dan mengumpulkan tugas/proyek secara keseluruhan. Selain itu problem dari pendidik yang masih kaku dalam proses pembelajaran, terbatasnya kemampuan komunikasi pendidik, dan minimnya pengalaman pendidik. Ada juga problem kurikulum, dari minimnya sarana prasarana yang belum menunjang pembelajaran sepenuhnya, terbatasnya waktu dalam proses pembelajaran. Itu semua dapat menyebabkan problematika pembelajaran interaktif dalam praktik pendidikan Islam. Maka menjadi solutif apabila problematika model pembelajaran dijadikan inovasi baik dari dinilai dari kekurangan dan kelebihannya. Karena proses belajar peserta didik akan dianggap lebih efektif apabila peserta didik setelah belajar bisa mengetahui sesuatu yang 
sebelumnya belum diketahui. Jadi, prestasi belajar akan berubah menjadi baik dengan adanya perubahan tingkah laku baru dalam tingkat akal pengetahuan, berpikir atau kemajuan potensi jasmaninya.

\section{DAFTAR PUSTAKA}

Abadi, Abi Thohir Ya'kub Al-Fairuz. 2001. Tanwirul Muqobas. Libanon: Beirut. Ali, Muhamad. 2009. "Pengembangan Media Pembelajaran Interaktif Mata Kuliah Medan Elektromagnetik." Jurnal Edukasi@Elektro 5(1):11-18.

Andayani, Abdul Majid dan Dian. 2005. Pendidikan Agama Islam Berbasis Kompetensi. Bandung: PT Remaja Rosdakarya.

Aunurrahman. 2009. Belajar Dan Pembelajaran. Bandung: CV Alfabeta.

Basri, Hasan. 2009. Filsafat Ilmu Pendidikan Islam. Bandung: Pustaka Setia.

Daradjat, Zakiah. 2009. Ilmu Pendidikan Islam. Jakarta: PT Bumi Aksara.

Dasna. 2015. "Desain Dan Model Dalam Bidang Pembelajaran Inovatif Dan Interaktif." Jurnal Ilmu Pendidikan.

Hamzah, Uno. 2007. Profesi Pendidikan. Jakarta: PT Bumi Aksara.

Irsyadi. 2011. "Peningkatan Hasil Belajar Operasi Hitung Bilangan Bulat

Melalui Model Pembelajaran Interaktif." Jurnal Cakrawala Pendidikan.

Majid, A. 2014. Strategi Pembelajaran. Bandung: PT Remaja Rosdakarya.

Majid, Abdul. 2013. Strategi Pembelajaran. Bandung: Rosda.

Muhibbin, Syah. 2000. Psikologi Pendidikan Dengan Pendekatan Baru. Bandung: PT Rosda Karya.

Nita, Nila Intan. 2018. "Problematika Pembelajaran Pendidikan Agama Islam Di Smk Saraswati Salatiga Tahun Pelajaran 2017/2018 Skripsi."

Nurdyansyah, and Eni Fariyatul Fahyuni. 2016. Inovasi Model.

Praja, Usman Effendi dan S. 1999. Pengantar Psikologi Pendidikan. Bandung: PT Angkasa.

Prayekti. 2004. "Penerapan Model Pembelajaran Interaktif Pada Mata Pelajaran IPA Di SD." Jurnal Teknologi Pendidikan.

Purwanto, M. Ngalim. 2004. Psikologi Pendidikan. Bandung: PT Remaja Rosdakarya.

Sanjaya, Wina. 2007. Strategi Pembelajaran Berorientasi Standar Proses

Pendidikan. Jakarta: Prenada Media Group.

Santosa. 2004. Dinamika Kelompok Edisi Revisi. Jakarta: Bumi Aksara.

Sardiman, A. .. 2012. Interaksi Dan Motivasi Belajar Mengajar. Jakarta: PT Raja Grafindo Persada.

Suharso, Aries. 2012. "Model Pembelajaran Interaktif Bangun Ruang 3D Berbasis Augmented Reality." Model Pembelajaran Interaktif Bangun Ruang 3D Berbasis Augmented Reality 11(24):1-11.

Surya, Moh. 2004. Psikologi Pembelajaran Dan Pengajaran. Bandung: Pustaka Bani Quraisy. 
Suryabrata, Sumadi. 1994. Psikologi Pendidikan. Jakarta: PT Raja Grafindo.

Trianto. 2007. Model-Model Pembelajaran Inovatif Berorientasi Konstruktivistik. Jakarta: PT Prestasi Pustaka.

Trianto. 2014. "Model Pembelajaran Terpadu." Konsep Strategi Dan Implementasinya Dalam KTSP.

Widiantono, Nugroho. 2017. "Penerapan Model Pembelajaran Interaktif Untuk Meningkatkan Aktivitas Dan Hasil Belajar Ipa Siswa Kelas 5 Sd.” Scholaria: Jurnal Pendidikan Dan Kebudayaan 7(3):199.

Widodo. 2007. "Pendidikan IPA Di SD." Jurnal Pendidikan Dasar. 